\title{
METALLOTHIONEINS CONTRIBUTION TO THE RESPONSE OF BIVALVE MOLLUSK TO XENOBIOTICS
}

\author{
V. V. KHOMA ${ }^{1}$, L. L. GNATYSHYNA ${ }^{1,2}$, V. V. MARTYNIUK ${ }^{1}$, \\ T. R. MACKIV ${ }^{1,2}$, N. Y. MISHCHUK ${ }^{1}$, O. B. STOLIAR ${ }^{1 \bowtie}$ \\ ${ }^{1}$ Ternopil Volodymyr Hnatiuk National Pedagogical University, Ukraine; \\ ${ }^{2}$ I.Ya. Horbachevsky Ternopil National Medical University, Ukraine; \\ ®e-mail: Oksana.Stolyar@tnpu.edu.ua
}

Received: 17 April 2020; Accepted: 25 June 2020

\begin{abstract}
Estimation of cellular thiols metallothioneins (MTs) sensitivity to continuous pressure of environmental chemical 'cocktail' of xenobiotics needs investigation in correct model experiments. The aim of this study was to elucidate MTs contribution into bivalve mollusk response to co-exposure to xenobiotics and elevated temperature. We treated the mussels Unio tumidus Philipson, 1788 (Unionidae) with drugs diclofenac (Dc, $2 \mathrm{nM}$ ), nifedipine (Nf, $2 \mathrm{nM}$ ) or with organophosphonate herbicide glyphosate (Gl, formulation Roundup $M A X, 79 \mathrm{nM}$ ) separately at $18^{\circ} \mathrm{C}$ and in combination at $18^{\circ} \mathrm{C}(\mathrm{DcN} f G \mathrm{l})$ and $25^{\circ} \mathrm{C}(\mathrm{DcN} f G \mathrm{l}+\mathrm{T})$ during 14 days. MTs were isolated from digestive gland by size-exclusion chromatography. The concentration of MTs in the tissue was assessed according to metals ( $\mathrm{Zn}, \mathrm{Cu}, \mathrm{Cd}$ ) in the eluted peak of MTs (MT-Me) and thiols (MT-SH) content. Tissue redox status was assessed using lactate/pyruvate ratio. The assay of cells viability was based on the lysosomes ability of hemocytes to concentrate the Neutral Red (NR) dye. It was found, that MT-SH content in the digestive gland was increased under all exposures. Treatment with Dc increased the level of $M T-M e$, whereas treatment with Gl decreased it and increased lactate/pyruvate ratio. Nf decreased this ratio by elevating pyruvate level and increased lysosomal membrane stability in hemocytes. At co-exposure to xenobiotics and elevated temperature the number of hemocytes with nuclear abnormalities was increased indicating the exceeding of organisms' adaptive limits. Multivariate statistical analyses showed negative correlations in pairs MT-SH/MT-Me and MT-SH/pyruvate and distinguished Gl and DcNfGl+T exposed groups from other groups.
\end{abstract}

Ke y wo rd s: metallothioneins, diclofenac, nifedipine, roundup, redox state, Bivalve mollusk.

I n Eastern European Countries, the involving of populations in the utilization of pharmaceutical and personal care chemicals has enhanced in the last decades. It combines with progress in the agricultural industry and collapse of water purification systems [1], resulting in the subjecting of the environment to continuous pressure of chemical 'cocktail' of xenobiotics each of them can cause the biological effect in the low nanomolar concentration and interact the effects of other compounds [2]. The climate changes can add unpredictable consequences to the biological effect of waterborne chemical substances, in particular associated with the local extreme events that are likely to occur in summer in most rivers [3, 4]. Therefore, the model experiments with subjecting of the organism to single suspected adverse effect in the optimal conditions can give distorted evidence of its ability to withstand this effect [2-5].

The aim of this study was to reflect the impact of environmentally relevant combined exposure to xenobiotics and elevated temperature on the organism. Bivalve mollusk Unio tumidus was selected as approved sentinel organism. We focused the expertise on the responses of low weight thermostable proteins metallothioneins (MTs). Specific ability of MTs to bind transitional metals is well known. However, these stress-related proteins are

(c) 2020 Khoma V. V. et al. This is an open-access article distributed under the terms of the Creative Commons Attribution License, which permits unrestricted use, distribution, and reproduction in any medium, provided the original author and source are credited. 
known to be involved into the responses of the organism to plural exposures that are not associated with the toxicity of typical MTs ligands, namely zinc, cadmium, copper $[4,5]$. The manifestation of MTs responsivity in these exposures can be the disturbance of metal-binding properties (low metalation or hypermetalation) [4]. For the exposures we selected an organophosphonate glyphosate as one of the most used herbicide worldwide [6], non-steroidal anti-inflammatory medicine diclofenac that is the priority substance in urban waters in Ukraine [7] and cheap antihypertensive nifedipine that is frequently utilized in the treatment of cardiovascular disease. In 2016 it was the $154^{\text {th }}$ most prescribed medication in the United States with more than four million prescriptions [8]. We expected that the combination of these aquatic pollutants and elevated temperature could reflect the impact of environmental combined stressors and to elucidate the participation of MTs in the expected response of the organism.

\section{Materials and Methods}

All reagents were of the Reagent grade or higher. They were obtained from Sigma-Aldrich (USA) or Synbias (Ukraine). Detailed information on exposures and assay characteristics is given in the Supplement available via the Mendeley Data by the following link: http://dx.doi. org/10.17632/82pyxwgm8h.1

Adult bivalve mollusks Unio tumidus Philipson, 1788 (Unionidae) ( 6 years old, $\sim 8.5 \mathrm{~cm}$ length, and 60-70 g weight) were collected in a river site assumed to be reference [4]. Specimens were transported to the laboratory and preacclimated to the laboratory conditions for up to seven days after the capture in the aerated, softened tap water $\left(17 \pm 1^{\circ} \mathrm{C}, \mathrm{pH} 7.3 \pm 0.2, \mathrm{CaCO}_{3}\right.$ level $86.8 \pm 1.0 \mathrm{mg} / \mathrm{l}$, dissolved oxygen level $8.67 \pm 0.51 \mathrm{mg} / \mathrm{l}$, ammonia $\left(\mathrm{NH}_{3} / \mathrm{NH}_{4}^{+}\right)$and nitrite levels below $\left.0.1 \mathrm{mg} / \mathrm{l}\right)$. Specimens were fed $500 \mathrm{mg}$ of Tropical SuperVit Basic contained beta-1.3/1.6-glucan twice a week. After that, mollusks were distributed randomly to six groups placed in the $80-\mathrm{L}$ tanks each. One group was exposed to the aquarium water only and was considered as control (C). Other five groups were exposed to diclofenac (Dc), nifedipine (Nf), organophosphonate pesticide glyphosate (Gl) separately at the temperature $18^{\circ} \mathrm{C}$ (positive controls) and jointly at the temperatures $18^{\circ} \mathrm{C}$ (DcNfGl) and $25^{\circ} \mathrm{C}$ (DcNfGl+T) during 14 days. The concentrations of substances were: Dc (Diclofenac-Darnitsa)
$600 \mathrm{ng} / \mathrm{l}$ or $2 \mathrm{nM}$; Nf (Nifedipinum Retard-Darnits) $700 \mathrm{ng} / \mathrm{l}$, or $2 \mathrm{nM}$ ); Gl (formulation Roundup MAX, Monsanto, USA), $33.8 \mu \mathrm{g} / \mathrm{l}$, of Roundup MAX corresponding to $13.4 \mu \mathrm{g} / \mathrm{l}$ or $\sim 79 \mathrm{nM}$ of $\mathrm{Gl}$. Water was changed and chemicals were replenished every two days. No mortality was observed during the experimental exposures.

Utilized concentrations of chemicals were correspondent to the levels indicated in the effluents of the municipal sewage treatment plants and/or freshwaters. For example, the concentration of Dc in Swiss lakes and rivers ranged from $<1$ to $12 \mathrm{ng} / \mathrm{l}$, with the highest detected concentration $310 \mathrm{ng} / \mathrm{l}$ [1]. $\mathrm{Nf}$ or its metabolites were detected in the sewage effluents in the ten to hundreds of $n g / 1$, despite $\mathrm{Nf}$ is easily degraded and light sensitive [9]. Environmentally realistic concentrations of Gl correspond to $\mu \mathrm{g} / \mathrm{l}$ [10]. The choice of the temperature regime was based on the preliminary experiments, when exposure of mollusks to $25^{\circ} \mathrm{C}$ during 14 days did not cause mortality, unlike exposure to $30^{\circ} \mathrm{C}$, and correspondence to the data on the surface water temperatures in Europe.

In the end of exposure, individual's length, total, soft body, digestive gland and gill weights were recorded. The condition factor (CF) of the animals was calculated by the following equation: $\mathrm{CF}=$ [total weight $(\mathrm{g}) /$ total length $\left.^{3}(\mathrm{~cm})\right] \times 100$. The condition indexes (CI) of soft tissue (ST) and digestive gland (DG), were calculated as the ratio: (weight of drained organ $(\mathrm{g}) /$ total weight $(\mathrm{g}) \times 100)$.

Lysosomal membrane stability and nuclear abnormalities were determined in hemocytes, all other indices - in digestive gland. Hemocytes were studied immediately, while digestive glands and thermostable eluate for MTs isolation were frozen $\left(-40^{\circ} \mathrm{C}\right)$ until further analyses. Hemolymph was withdrawn from the adductor muscle sinus using a hypodermic syringe that contained $200 \mu \mathrm{l}$ of phosphate-buffered saline ( $\mathrm{pH}$ 7.4). Hemocytes were pelleted at $250 \mathrm{~g}$, resuspended in phosphate-buffered saline /EDTA (v/v 1:1), diluted to a density of $4 \times 106$ cells $\cdot \mathrm{ml}^{-1}$, then aliquoted to analysis.

Metallothioneins (MTs) were isolated as the thermostable proteins by size-exclusion chromatography on Sephadex G-50 as described elsewhere [5]. For each replicate, tissues from five individuals of a certain experimental group were pooled to the total of $350 \mathrm{mg}$. The MTs-contained peak was identified based upon its spectral features (peak of absorbance at $245 \mathrm{~nm}$ and the absence of peak at 
$280 \mathrm{~nm}$ ) and low molecular weight. The concentration of $\mathrm{Cu}, \mathrm{Zn}$ and $\mathrm{Cd}$ was measured in the eluate, contained MTs after the digestion of dried samples with $\mathrm{HNO}_{3}$. Concentration of MTs in the tissue of digestion gland was assessed by two approaches: from metals contained in the eluted peak of MTs (MT$\mathrm{Me}$ ) and from the concentration of thiols (MT-SH) using 5,5-dithio-bis-(2-nitrobenzoic acid) reduction method after the ethanol/chloroform extraction from tissue homogenate [11]. MT-Me concentration was estimated from the metal ( $\mathrm{Zn}, \mathrm{Cu}, \mathrm{Cd}$ ) analysis, considering that one molecule of MT binds seven $\mathrm{Zn}^{2+}$ or $\mathrm{Cd}^{2+}$ ions or twelve $\mathrm{Cu}^{+}$in two thiolate domains [12]. The levels of MT-SH were calculated assuming the relationship: $1 \mathrm{~mol}$ of MTs is equal to $21 \mathrm{~mol}$ of GSH [13] and using a molar extinction coefficient of 5-thio-2-nitrobenzoate of $13,600 \mathrm{M}^{-1} \cdot \mathrm{cm}^{-1}$. MTs concentration (MT-SH and MT-Me) was expressed as $\mu \mathrm{g}$ of MTs per g of wet tissue weight (FW), assuming that molecular weight of mollusk MT is $\sim 8.6 \mathrm{kDa}$ [13].

Tissue redox status was assessed using the lactate/pyruvate ratio. Lactate and pyruvate concentrations were analyzed with standard spectrophotometric methods using bacterial D-Lactate Dehydrogenase (EC 1.1.1.28) as a coupling enzyme [14] in the presence of NAD or NADH correspondingly. Differences in the absorbance at $340 \mathrm{~nm}$ were used to calculate lactate or pyruvate concentrations of the samples using the millimolar extinction coefficient for NADH of $\varepsilon_{\mathrm{M}}=6.22 \mathrm{mM}^{-1} \cdot \mathrm{cm}^{-1}$.

The assay of cells viability was based on the lysosomes ability to concentrate the Neutral Red (NR) dye adopted to freshwater mussels by using Ringer's solution [15]. Haemolymph collected from the adductor muscle of specimens was incubated on a glass slide with a freshly prepared NR solution. Following uptake and binding of neutral red in lysosomes, the proportion of cells exhibiting loss of dye from lysosomes was recorded at 1,000 $\times$ magnification until loss was observed in more than $50 \%$ cells. Observations for NR retention (NRR) were recorded at 5-min intervals. The NRR time was estimated as the time at which $50 \%$ of hemocytes released their accumulated NR.

For the determining of nuclear lesions, the suspension of hemocytes was fixed in methanol/ acetic acid (3/1), stained with 5\% Giemsa and mount in Canada balsam. The stained slides were analyzed under the light microscope at $1,000 \times$ magnification). Micronuclei, as well as hemocytes with lobed nuclei
(L), dumbbell-shaped or segmented nuclei (S), and kidney-shaped nuclei (K) were registered. Frequency of nuclear lesions were assessed jointly for all lesions $(\mathrm{MN}+\mathrm{L}+\mathrm{S}+\mathrm{K})$ and expressed per 1,000 cells [16]. At least 2,000 cells were assessed in each sample.

Thermostable proteins analyses were carried out in triplicate for two independent replicates derived of pooled tissues from five mussels. For all other traits, sample size was eight. Results were expressed as mean \pm SD. Shapiro-Wilk test was used for the assessment of normality. Data were analyzed with parametric Student's t-test significant at $P<0.05$. Principal component analysis (PCA) was performed to assess the relations between measured parameters utilizing rotation method Varimax with Kaiser Normalization, and Canonical discriminant analysis was utilized for the separation of the different groups. The IBM SPSS Statistics version 24 software for Windows were used for calculations.

\section{Results and Discussion}

The concentration of MT-SH increased in all exposures, particularly in Gl-group and co-exposures (by 26-48\%) (Fig. 1, A). The level of MT-Me was changed with another regularity: it was increased by Dc, dropped by Gl (by 41\%), and was not changed as compared to control in other exposures (Fig. 1, $B$ ). As a result, the imbalance of MT-SH/MTMe with the elevated part of low metalated MTs was shown in all Gl-related exposures, most prominently in the exposure to Gl (Fig. 1, C).

All exposures affected the concentrations of lactate and/or pyruvate (Fig. 2). Under the exposures to Dc and Gl, the level of lactate decreased. The Nf increased the level of pyruvate, whereas Glcontained exposures decreased it by $\sim 2-3$ times. As a result, the lactate/pyruvate ratio was decreased under the exposure to $\mathrm{Nf}$ leading to the decrease of the redox status, and increased by the effect of G1 and co-exposures, providing the anaerobic shift and increase of the redox state in the tissue. The effect of Dc on the redox balance was less pronounced.

The determining of cell viability has shown the similarity for all Nf-containing exposures: increase of the time of the retention of the dye within the lysosomes. On the other hand, Dc and Gl did not affect the lysosomal membrane stability (Fig. 3, A). The number of hemocytes with nuclear abnormalities was increased in both co-exposures by 1.5-1.7 times and did not differ from control in all single exposures (Fig. 3, B). 

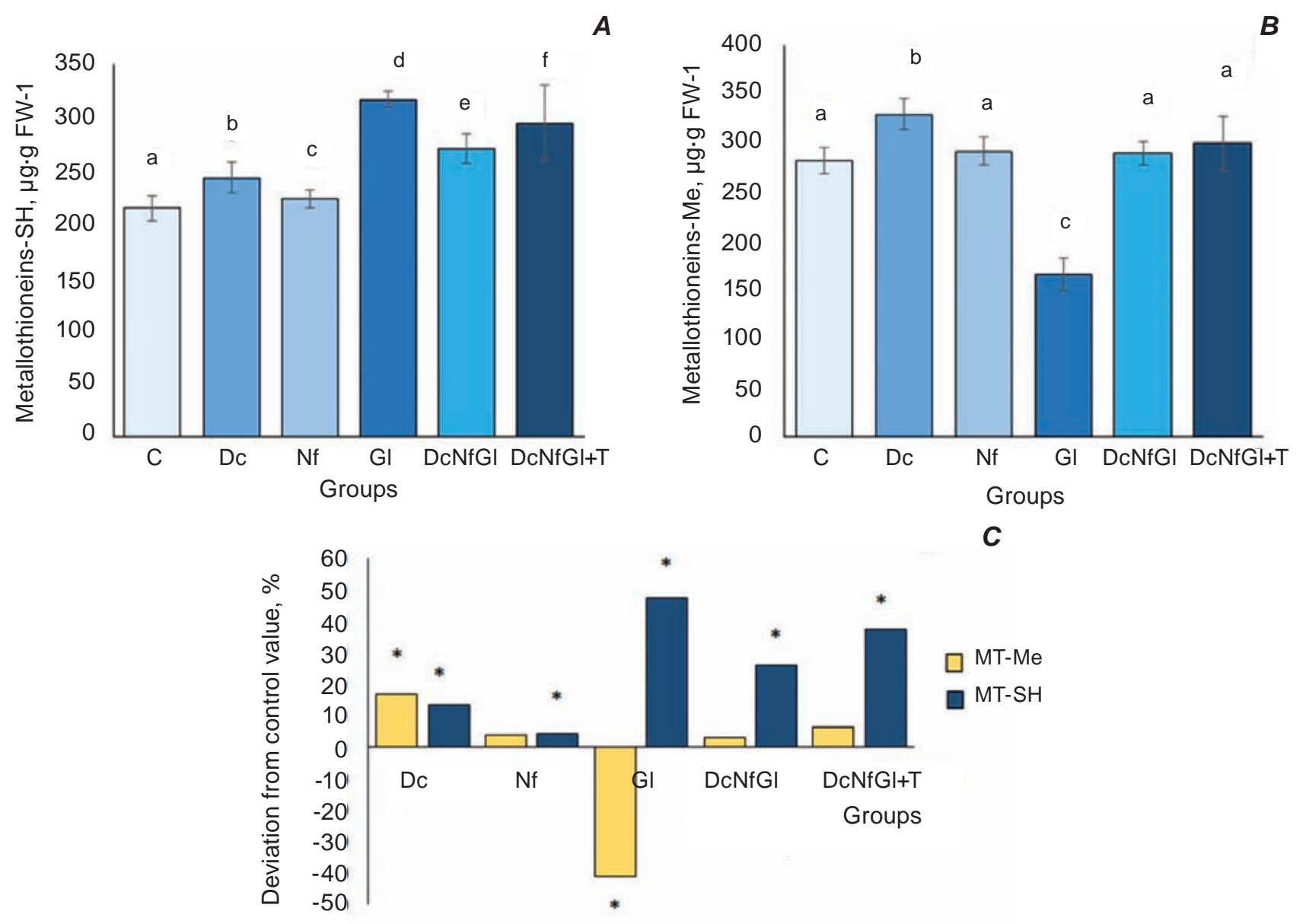

Fig. 1. Effects of experimental exposures of U. tumidus to diclofenac (Dc), nifedipine (Nf), glyphosate (Gl) and their combinations at $18^{\circ} \mathrm{C}(\mathrm{DcNfGl})$ and $25^{\circ} \mathrm{C}(\mathrm{DcNfGl}+\mathrm{T})$ during 14 days on tissue levels of metallothionein protein, MT-SH (A), metalated metallothionein MT-Me (B) and their differences compared to control (C). Data are presented as means $\pm S D, n=8$ for MT-SH, and $n=6$ (of 2 joined samples from 5 individuals) for MT-Me. In A, B, different letters above the columns indicate significantly different values $(P<0.05)$; in $\boldsymbol{C}, *$ is corresponding to significant difference compare to control value $(P<0.05)$.

The exposures affected the morphological indices of mollusks (Table), particularly by increasing of $\mathrm{CI}$ of the digestive gland in the exposures to $\mathrm{Gl}$ and GcNfGl+T by 64.2 and $40.8 \%$ correspondingly. Only in the Dc-group all morphological indices corresponded to the control values.

According to PCA, MT-SH and MT-SH/MTMe were located opposite MT-Me $(r=-0.570$ and -0.936, $P<0.01$ correspondingly) and pyruvate relating Factor 1 (Fig. 4, A). MT-SH had also negative correlation with pyruvate, $r=-0.526, P<0.01$ and positive correlation with lactate/pyruvate ratio $(r=0.488, P<0.01)$ and CI $(r=0.448, P<0.01)$ (Fig. 4, A). The indices of hemocytes, NRR time, and nuclear abnormalities, were not included in the Rotated Factor Matrix by PCA. Multivariate analysis classified correctly more than $91.7 \%$ of cross-validated groups with the actual prediction equation for Functions 1 and 2: Function $1=2.865+7.205$ MTSH/MT-Me + 0.094 NRR - 0.042 CI - 0.030 MT$\mathrm{Me}-0.026$ Lactate/pyruvate. Function $2=-38.543$ + 11.551 MT-SH/MT-Me + 0.104 Lactate/pyruvate + 0.094 MTMe - 0.020 CI - 0.019 MT-Me. According to results of canonical discriminant analysis, overall, the Gl group had the opposite position and high distance compare to all other groups relating Function 1; and DcNfGl+T group was most distinct from control relating Function 2 (Fig. 4, B).

Concentrations of MT-SH and MT-Me are seldom compared in the same study, despite this comparison can give valuable information concerning the participation of these multifunctional proteins in 

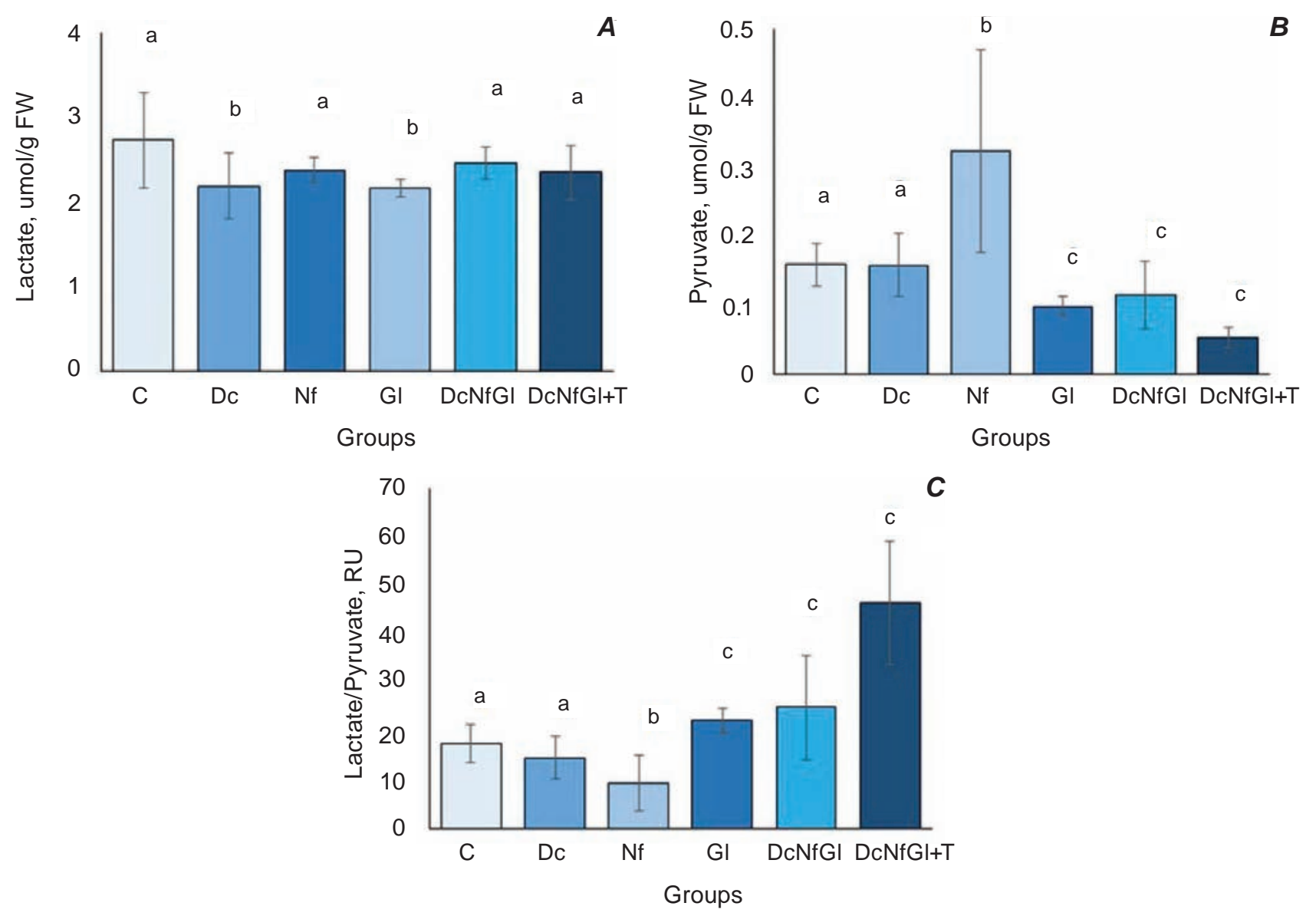

Fig. 2. Tissue levels of metabolites in the digestive gland of U. tumidus from the control $(C)$ and groups exposed to diclofenac (Dc), nifedipine (Nf), glyphosate (Gl) and their combinations at $18^{\circ} \mathrm{C}$ (DcNfGl) and $25^{\circ} \mathrm{C}$ (DcNfGl+T) during 14 days: $\boldsymbol{A}$ - lactate, $\boldsymbol{B}$ - pyruvate, $\boldsymbol{C}$ - lactate/pyruvate ratio. Data are presented as means $\pm S D(n=8)$. Different letters above the columns indicate significantly different values $(P<0.05)$

the antioxidant defense, metal chelating and distribution within the cells [4, 17-19]. The increase of the MTs protein concentration (MT-SH) was indicated in laboratory and field exposures to different adverse effects [19-21]. Similarly to our results, the sensitivity of MTs to Gl was shown in the adult rats administered by Gl during 15 days [22]. In this study, Gl up-regulated metallothionein (MT I and MT II) genes expression in the liver, however the concentration of resulted MT protein was not studied. To the best of our knowledge, the loss of metal-binding activity of MTs in the exposure to Gl was detected for the first time in our study. It can be explained by the presence of other metal-chelators or/and the changes in the redox-state of SH-groups. Particularly, the indicated imbalance of MT-SH and MT-Me in the exposures to $\mathrm{Gl}$ and its combinations can be related to known chelating activity of this substance concerning metals [23]. Indeed, even if the MTs ex- pression is activated, the decrease of the chelating ability of MTs can occur [24].

Similarly to our finding, loss of the metalbinding ability despite the up-regulation of MTs protein was shown in the exposures of mollusks to different other substances, including a high concentration of $\mathrm{Nf}(10 \mu \mathrm{M})$ and complex exposures in situ $[19,21]$. Importantly, the thermal constituent of the complex exposures was shown to disrupt the function of MTs in the complex exposures. For example, exposure at the elevated temperature $\left(25^{\circ} \mathrm{C}\right)$ strongly suppressed the MTs response of $U$. tumidus to $\mathrm{ZnO}$ nanoparticles [21]. However, in the present study, the Gl had the prevalent impact on the metal-binding properties of MTs, and the co-exposure masked it partly. Discriminant analysis confirms the particular effect of Gl, as well as the most distinct from control response to co-exposure (DcNfGl+T) among the rest groups (Fig. 4, B). 

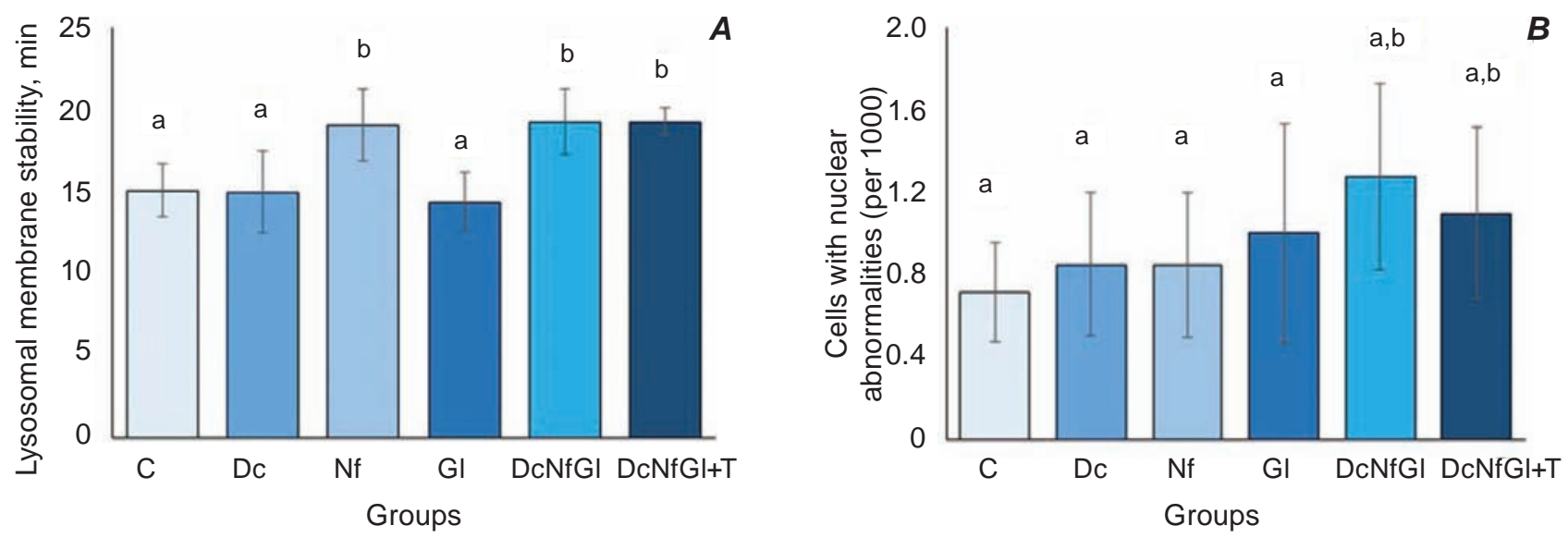

Fig. 3. Toxicity parameters in hemocytes of U. tumidus from the control (C) and groups exposed to diclofenac (Dc), nifedipine (Nf), glyphosate (Gl) and their combinations at $18^{\circ} \mathrm{C}(\mathrm{DcNfGl})$ and $25^{\circ} \mathrm{C}(\mathrm{DcNfGl}+\mathrm{T})$ during 14: $\boldsymbol{A}$ - lysosomal membrane stability; $\boldsymbol{B}$ - frequencies of the hemocytes with the micronuclei and other nucleus abnormalities. Data are presented as means $\pm S D(n=8)$. Different letters above the columns indicate significantly different values $(P<0.05)$

Morphological indices of the Unio tumidus exposed to Diclofenac (Dc), Nifedipine (Nf), Glyphosate (Gl) and their mix at temperatures $18^{\circ} \mathrm{C}(D G N f G l)$ and $25^{\circ} \mathrm{C}(D G N f G l+T)$ during 14 days $(M \pm S D, n=8)$

\begin{tabular}{l|c|c|c|c|c|c|c}
\hline Group & $\begin{array}{c}\text { Body } \\
\text { length, cm }\end{array}$ & $\begin{array}{c}\text { Total body } \\
\text { weight, g }\end{array}$ & $\begin{array}{c}\text { Shell } \\
\text { weight, g }\end{array}$ & $\begin{array}{c}\text { Digestive } \\
\text { gland } \\
\text { weight, g }\end{array}$ & CF, \% & $\begin{array}{c}\text { CI soft } \\
\text { tissues, \% }\end{array}$ & $\begin{array}{c}\text { CI } \\
\text { digestive } \\
\text { gland, \% }\end{array}$ \\
\hline C & $8.46 \pm 0.48^{\mathrm{a}}$ & $61.3 \pm 5.1^{\mathrm{a}}$ & $22.6 \pm 2.1^{\mathrm{a}}$ & $0.74 \pm 0.14^{\mathrm{a}}$ & $10.3 \pm 1.7^{\mathrm{a}}$ & $63.2 \pm 0.9^{\mathrm{a}}$ & $1.20 \pm 0.20^{\mathrm{a}}$ \\
$\mathrm{Dc}$ & $8.30 \pm 0.26^{\mathrm{a}}$ & $59.8 \pm 7.5^{\mathrm{a}}$ & $22.5 \pm 3.4^{\mathrm{a}}$ & $0.70 \pm 0.25^{\mathrm{a}}$ & $10.5 \pm 1.4^{\mathrm{a}}$ & $62.4 \pm 3.2^{\mathrm{a}}$ & $1.17 \pm 0.40^{\mathrm{a}}$ \\
$\mathrm{Nf}$ & $8.41 \pm 0.81^{\mathrm{a}}$ & $74.10 \pm 18.14^{\mathrm{b}}$ & $24.1 \pm 5.8^{\mathrm{a}}$ & $0.70 \pm 0.10^{\mathrm{a}}$ & $12.4 \pm 2.2^{\mathrm{b}}$ & $67.3 \pm 2.8^{\mathrm{b}}$ & $0.97 \pm 0.16^{\mathrm{b}}$ \\
Gl & $8.30 \pm 0.33^{\mathrm{a}}$ & $64.1 \pm 8.5^{\mathrm{a}}$ & $22.3 \pm 3.2^{\mathrm{a}}$ & $1.26 \pm 0.77^{\mathrm{b}}$ & $11.2 \pm 0.8^{\mathrm{a}}$ & $65.2 \pm 1.7^{\mathrm{b}}$ & $1.97 \pm 1.16^{\mathrm{c}}$ \\
DcNfGl & $8.46 \pm 0.76^{\mathrm{a}}$ & $64.6 \pm 13.2^{\mathrm{a}}$ & $25.3 \pm 5.8^{\mathrm{a}}$ & $0.74 \pm 0.09^{\mathrm{a}}$ & $10.9 \pm 2.8^{\mathrm{a}}$ & $60.7 \pm 5.2^{\mathrm{ac}}$ & $1.20 \pm 0.31^{\mathrm{a}}$ \\
DcNfGl+T & $8.43 \pm 0.30^{\mathrm{a}}$ & $58.3 \pm 6.6^{\mathrm{a}}$ & $21.1 \pm 2.6^{\mathrm{ab}}$ & $1.01 \pm 0.46^{\mathrm{a}}$ & $9.7 \pm 0.8^{\mathrm{a}}$ & $63.7 \pm 1.9^{\mathrm{a}}$ & $1.69 \pm 0.69^{\mathrm{c}}$ \\
\hline
\end{tabular}

Note. In each column, data that are significantly different have different indexes, $P<0.05$.

The MTs functionality can be depending on the redox state in the cell [24]. The ratio lactate/pyruvate indicates this state to some extent [25]. Overall, in this study, the difference in the utilization of pyruvate was the main reason for change in the lactate/ pyruvate ratio, whereas the level of lactate was rather stable. Pyruvate is a keystone molecule critical for numerous aspects of eukaryotic and human metabolism [26]. In different extreme situations, this endproduct of a metabolic breakdown in the cellular cytoplasm drives ATP production in the mitochondrion by oxidative phosphorylation. In bivalve mollusks the particular anaerobic utilization of pyruvate in the cytosol with the formations of opines is known [27]. In any case, in this study, the Gl and co-exposures caused the similar directions (up-regulation) in the responses of MT-SH and lactate/pyruvate ratio, confirmed by PCA and correlation analysis. In opposite, $\mathrm{Nf}$ caused increase of pyruvate level. This particular effect of $\mathrm{Nf}$ can be the result of the suppression of $\mathrm{Ca}^{2+}$-dependent mitochondrial energy metabolism due to the blockage of $\mathrm{Ca}^{2+}$ entry [15]. The dependence of MTs functionality on the anaerobic state was reported both for mollusks and for higher vertebrate $[24,28]$.

The lysosomal membrane stability test is frequently used for the evaluation of cell vitality [29]. Interestingly, we did not indicate the decrease of NRR time in any group (Fig. 3, A). In opposite, Nf and co-exposures caused its increasing. This unusual stabilizing effect of $\mathrm{Nf}$ on the lysosomal membranes was reported earlier and explained as the con- 
A

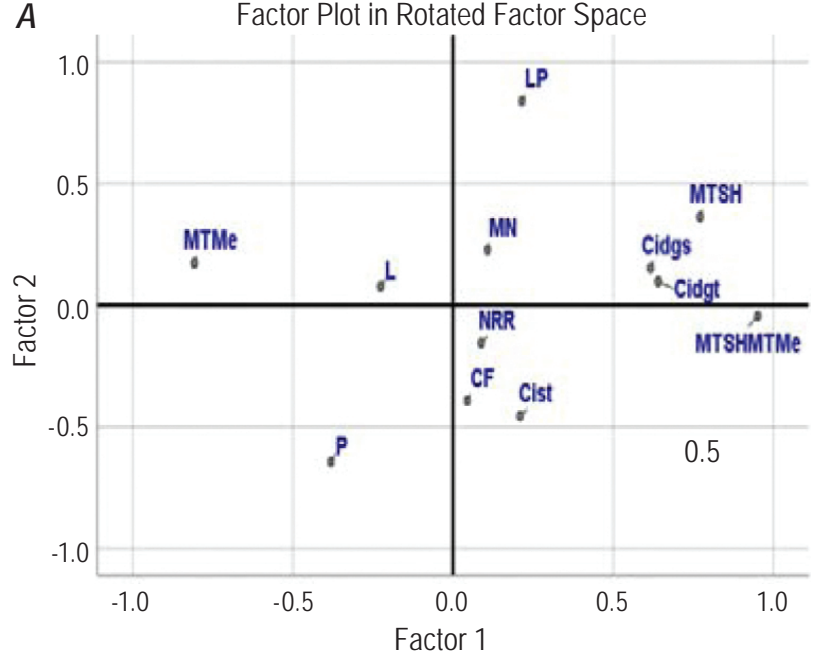

B

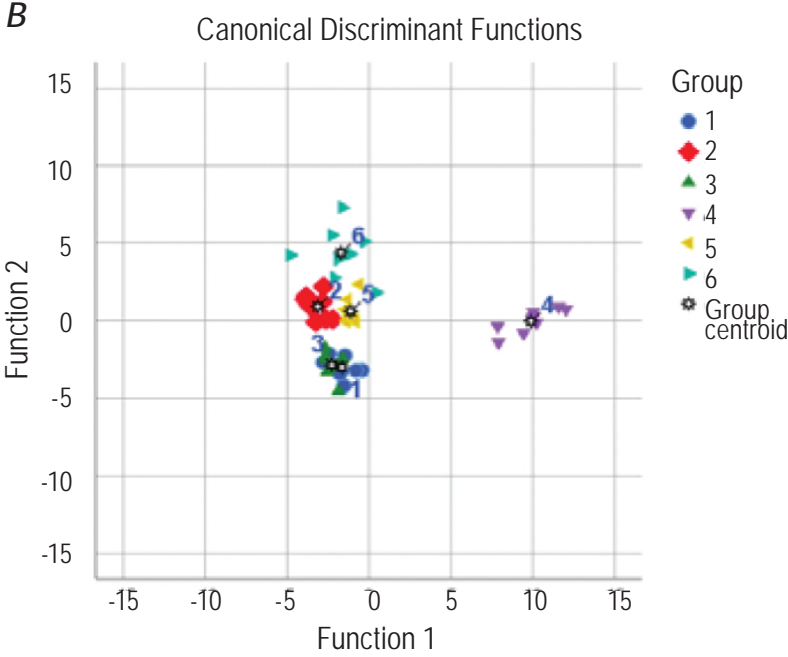

Fig. 4. The results of principal component analysis applied to reveal the relations between measured parameters (A) and scatter plots of the canonical values to discriminant the groups of mollusks (B). A: MTSH, MTMe, MTSHMTME - metallothionein characteristics; L- lactate, $P$ - pyruvate, LP - lactate/pyruvate ratio; $M N$ - nuclear abnormalities, NRR - lysosomal membrane stability; CF - condition factor; Cist, Cidgt, Cidgs - condition indexes of soft tissues and digestive gland relating total and soft tissues correspondingly. B: 1 - control group; 2, 3, 4, 5, 6 - Dc, Nf, Gl, DcNfGl, and DcNfGl+T groups

sequence of reduced Ca level in the cells [30]. The results of the determining of nuclear abnormalities have given the important evidence of the synergistic toxicity of co-exposures. The same effect of the elevated genotoxicity compare to single exposures was reported for the co-exposure of mollusks to $\mathrm{Nf}$ $(10 \mu \mathrm{M})$ and $\mathrm{ZnO}$ nanoparticles in our previous study [21].

Increase of $\mathrm{CI}$ of the digestive gland in the exposures to Gl and DcNfGl+T can reflect the metabolic injury. Similarly, the highest values for the CI of the digestive gland were reported for the mussels from the areas subjected to municipal effluents [31] or to chronic warming [32]. According to PCA (Fig. 4, A), the disturbance of MTs functionality and anaerobic shift in the digestive gland of mussels were associated with this sign of toxicity.

The presented research adds to the knowledge concerning the biochemical responses to each studied substance. Indeed, the studies of their effect in the non-targeted organisms are scant. They mostly related to acute exposures or high concentrations. For example, Dc affected the tissue integrity and immune activity in brown trout at the $5-50 \mu \mathrm{g} / \mathrm{l}$ [2] and was toxic for bivalve mollusk with an $\mathrm{LC}_{50}$ of $178 \mu \mathrm{g} / \mathrm{l}$ [33]. However, even low concentrations of Dc (20, 200, $2000 \mathrm{ng} / \mathrm{l})$ decreased the lysosomal membrane stability and COX activity in the brown mussel Perna perna exposed for 48 and $96 \mathrm{~h}$, as well as triggered DNA damage, oxidative stress and changes in antioxidant defenses [34]. Concerning Nf, acute ecotoxicity studies still predominate relatively to the chronic ones [35]. Importantly, the $\mathrm{Nf}$ affected membrane-relating functions in bivalve mollusk at the concentration of $10 \mu \mathrm{M}$ separately and in the coexposures [21]. The effects of environmentally realistic concentrations of pure $\mathrm{Gl}\left(10\right.$ and $\left.100 \mu \mathrm{g} \cdot \mathrm{l}^{-1}\right)$ to the mussels were studied for the first time recently [36]. It was indicated some alterations in the haemocyte parameters but low sensitivity of the oxidative stress indexes. The particular contribution of surfactant in the commercial formulations of Gl (Roundup) has been reported for juvenile oysters (Crassostrea gigas) [10].

Nevertheless, the application of the MTs analysis with the utilizing of the imbalance of total MTs and its metalated form and its relation to the redox parameters was undergoing for the first time for studied substances and their combinations. This allowed clear differentiate impact in the environmentally realistic model, depending on the MT-SH/MTMe imbalance. In the co-exposures its impact was also present but leveled. Similarly, the modulation of the effect of single substance ( $\mathrm{ZnO}$ nanoparticles) we observed in co-exposure with heating earlier [21]. In the present study, synergistic cumulative ef- 
fect of xenobiotics and heating was best shown as the nuclear lesions. The inconsistent and unpredictable consequences and the greatest effect of the exposure to mixtures of pharmaceuticals including Dc in environmentally realistic concentration were shown to Daphnia magna over six generations [37]. Therefore, the genotoxicity of the co-exposures causes great concern by the exceeding of the adaptive limits of the organism in the model approximated to environmental conditions.

The study of metallothioneins functionality, both as stress-related thiols and metal-binding proteins, allowed to indicate their sensitivity to environmentally realistic concentrations of substances of environmental priority and track some their particular impacts in the co-exposures. The relation between the metallothioneins activity and cellular redox state needs further elucidation.

Conflict of interest. Authors have completed the Unified Conflicts of Interest form at http://ukrbiochemjournal.org/wp-content/uploads/2018/12/ coi_disclosure.pdf and declare no conflict of interest.

Funding. This work has been granted by the Ministry of Education and Science of Ukraine (Project 132B for O. Stoliar).

\section{МЕТАЛОТІОНЕЇНИ В РЕАКЦІї ДВОСТУЛКОВОГО МОЛЮСКА НА ДІЮ КСЕНОБІОТИКІВ}

\section{В. В. Хома 1 , Л. Л. Гнатишина ${ }^{1,2}$, В. В. Мартинюк ${ }^{1}$, Т. Р. Мацьків ${ }^{1,2}$, Н. Й. Мішук ${ }^{1}$ О. Б. Столяр ${ }^{1 \rrbracket}$}

\footnotetext{
${ }^{1}$ Тернопільський національний педагогічний університет імені Володимира Гнатюка, Україна;

${ }^{2}$ Тернопільський національний медичний університет імені І. Я. Горбачевського, Україна;

凶e-mail: Oksana.Stolyar@tnpu.edu.ua
}

Оцінка чутливості клітинних тіолів металотіонеїнів (МТ) до тривалої дії екологічно реального хімічного «коктейлю» ксенобіотиків потребує дослідження з використанням коректних моделей. Метою роботи було з'ясувати внесок МТ у відповідь двостулкового молюска на сумісну дію ксенобіотиків і підвищеної температури. Молюсків Unio tumidus Philipson, 1788 p. (Unionidae) інкубували в розчинах препаратів диклофенаку (Dc, 2 нM), ніфедипіну (Nf, 2 нM) та органофосфонатного гербіциду гліфосату
(G1, препарат Roundup MAX, 79 нM) окремо та за комбінованої дії за $18^{\circ} \mathrm{C}\left(\right.$ DcNfGl) та $25^{\circ} \mathrm{C}$ (DcNfGl+T) протягом 14 днів. МТ травної залози виділяли гель-розподільчою хроматографією та визначали вміст МТ-Ме за кількістю зв'язаного ними металу $(\mathrm{Zn}, \mathrm{Cu}, \mathrm{Cd})$ та за концентрацією тіолів (MT-SH). Концентрація MT-SH у травній залозі молюсків виявилась підвищеною в усіх експозиціях. Встановлено, що у той самий час рівень МТ-Ме за дії Dc підвищувався, за дії Glвмісних розчинів частка МТ-Ме знижувалась та зростало співвідношення лактат/піруват. Nf зменшував це співвідношення, збільшуючи концентрацію пірувату, та підвищував стабільність лізосомальних мембран у гемоцитах. За сумісної дії ксенобіотиків та підвищеної температури збільшувалась кількість гемоцитів із ядерними порушеннями, що свідчить про перевищення адаптаційного потенціалу організму. Багатофакторний статистичний аналіз підтвердив негативні кореляції у парах MT-SH/MT-Mе та MT$\mathrm{SH} /$ піруват та відокремив групи Gl i DcNfGl+T від інших груп.

К л ю ч о в і с ло в а: металотіонеїни, диклофенак, ніфедипін, раундап, двостулковий молюск.

\section{References}

1. Ebele AJ, Abdallah M, Harrad S. Pharmaceuticals and personal care products (PPCPs) in the freshwater aquatic environment. Emerg Contam. 2017; 3(1): 1-16.

2. Holmstrup M, Bindesbøl AM, Oostingh JO, Duschl A, Scheil V, Köhler H, Loureiro S, Soares AM, Ferreira AL, Kienle C, Gerhardt A, Laskowski R, Kramarz PE, Bayley M, Svendsen C, Spurgeon DJ. Interactions between effects of environmental chemicals and natural stressors: a review. Sci Total Environ. 2010; 408(18): 3746-3762.

3. Benateau S, Gaudard A, Stamm C, Altermatt F. Climate change and freshwater ecosystems: Impacts on water quality and ecological status. Hydro-CH2018 Project. Federal Office for the Environment (FOEN), Bern, Switzerland. 110 p.

4. Gnatyshyna L, Khoma V, Mishchuk O, Martinyuk V, Springge G, Stoliar O. Multi-marker study of the responses of the Unio tumidus from the areas of small and micro hydropower plants at the Dniester River Basin, Ukraine. Environ Sci Pollut Res Int. 2020;2 7(10): 11038-11049. 
5. Gnatyshyna L, Falfushynska H, Horyn O, Khoma V, Martinyuk V, Mishchuk O, Mishchuk N, Stoliar O. Biochemical responses of freshwater mussel Unio tumidus to titanium oxide nanoparticles, Bisphenol A, and their combination. Ecotoxicology. 2019; 28(8): 923-937.

6. Annett R, Habibi HR, Hontela A. Impact of glyphosate and glyphosate-based herbicides on the freshwater environment. $J$ Appl Toxicol. 2014; 34(5): 458-479.

7. Vystavna Y, Frkova Z, Celle-Jeanton H, Diadin D, Huneau F, Steinmann M, Crini N, Loup C. Priority substances and emerging pollutants in urban rivers in Ukraine: Occurrence, fluxes and loading to transboundary European Union watersheds. Sci Total Environ. 2018; 637-638: 1358-1362.

8. The Top 300 of 2020. Provided by the ClinCalc DrugStats Database. Available at https://clincalc. com/DrugStats/Top300Drugs.aspx (accessed, March, 2020).

9. Kolpin DW, Furlong ET, Meyer MT, Thurman EM, Zaugg SD, Barber LB, Buxton HT. Pharmaceuticals, hormones, and other organic wastewater contaminants in U.S. streams, 19992000: a national reconnaissance. Environ Sci Technol. 2002; 6(6): 1202-1211.

10. Séguin A, Mottier A, Perron C, Lebel JM, Serpentini A, Costil K. Sub-lethal effects of a glyphosate-based commercial formulation and adjuvants on juvenile oysters (Crassostrea gigas) exposed for 35 days. Mar Pollut Bull. 2017; 117(1-2): 348-358.

11. Viarengo A, Ponzano E, Dondero F, Fabbri R. A simple spectrophotometric method for metallothionein evaluation in marine organisms: an application to Mediterranean and Antarctic Molluscs. Mar Environ Res. 1997; 44(1): 69-84.

12. Nielson KB, Winge DR. Independence of the domains of metallothionein in metal binding. $J$ Biol Chem. 1985; 260(15): 8698-8701.

13. Mackay EA, Overnell J, Dunbar B, Davidson I, Hunziker PE, Kägi JH, Fothergill JE. Complete amino acid sequences of five dimeric and four monomeric forms of metallothionein from the edible mussel Mytilus edulis. Eur J Biochem. 1993; 218(1): 183-194.

14. Gawehn K, Bergmeyer HU. D-(-)-Lactate. Methods Enzymatic Anal. 1988; 6: 588-592.

15. Repetto G, del Peso A, Zurita JL. Neutral red uptake assay for the estimation of cell viability/ cytotoxicity. Nat Protoc. 2008; 3(7): 1125-1131.
16. Baršienè J, Andreikenaite L, Rybakovas A. Cytogenetic damage in perch (Perca fluviatilis L.) and duck mussel (Anodonta anatina L.) exposed to crude oil. Ekologija. 2006; 1: 25-31.

17. Roesijadi G, Fowler BA. Purification of invertebrate metallothioneins. Methods Enzymol. 1991; 205: 263-273.

18. Lee SJ, Koh JY. Roles of zinc and metallothionein-3 in oxidative stress-induced lysosomal dysfunction, cell death, and autophagy in neurons and astrocytes. Mol Brain. 2010; 3(1): 30.

19. Zorita I, Strogyloudi E, Buxens A, Mazón LI, Papathanassiou E, Soto M, Cajaraville MP. Application of two SH-based methods for metallothionein determination in mussels and intercalibration of the spectrophotometric method: laboratory and field studies in the Mediterranean Sea. Biomarkers. 2005; 10(5): 342-359.

20. Isani G, Carpenè E. Metallothioneins, unconventional proteins from unconventional animals: a long journey from nematodes to mammals. Biomolecules. 2014; 4(2): 435-457.

21. Falfushynska H, Gnatyshyna L, Yurchak I, Sokolova I, Stoliar O. The effects of zinc nanooxide on cellular stress responses of the freshwater mussels Unio tumidus are modulated by elevated temperature and organic pollutants. Aquat Toxicol. 2015; 162: 82-93.

22. Soudani N, Chaâbane M, Ghorbel I, Elwej A, Boudawara T, Zeghal N. Glyphosate disrupts redox status and up-regulates metallothionein I and II genes expression in the liver of adult rats. Alleviation by quercetin. Gen Physiol Biophys. 2019; 38(2): 123-134.

23. Mesnage R, Antoniou MN. Facts and fallacies in the debate on glyphosate toxicity. Front Public Health. 2017; 5: 316.

24. Krężel A, Maret W. The Functions of Metamorphic Metallothioneins in Zinc and Copper Metabolism. Int J Mol Sci. 2017; 18(6): 1237.

25. Sun F, Dai C, Xie J, Hu X. Biochemical issues in estimation of cytosolic free NAD/NADH ratio. PLoS One. 2012; 7(5): e34525.

26. Gray LR, Tompkins SC, Taylor EB. Regulation of pyruvate metabolism and human disease. Cell Mol Life Sci. 2014; 71(14): 2577-2604.

27. Bacchiocchi S, Principato G. Mitochondrial contribution to metabolic changes in the digestive gland of Mytilus galloprovincialis 
during anaerobiosis. J Exp Zool. 2000; 286(2): 107-113.

28. English TE, Storey KB. Freezing and anoxia stresses induce expression of metallothionein in the foot muscle and hepatopancreas of the marine gastropod Littorina littorea. J Exp Biol. 2003; 206(Pt 14): 2517-2524.

29. Viarengo A, Lowe D, Bolognesi C, Fabbri E, Koehler A. The use of biomarkers in biomonitoring: a 2-tier approach assessing the level of pollutant-induced stress syndrome in sentinel organisms. Comp Biochem Physiol C Toxicol Pharmacol. 2007; 146(3): 281-300.

30. Elferink JG. Interference of the calcium antagonists verapamil and nifedipine with lysosomal enzyme release from rabbit polymorphonuclear leukocytes. Arzneimittelforschung. 1982; 32(11): 1417-1420.

31. Newton TJ, Cope WG. Biomarker responses of unionid mussels to environmental contaminants. Freshw Bivalve Ecotoxicol. 2007; 257-284.

32. Payton SL, Johnson PD, Jenny MJ. Comparative physiological, biochemical and molecular thermal stress response profiles for two unionid freshwater mussel species. J Exp Biol. 2016; 219(Pt 22): 3562-3574.

33. Parolini M, Binelli A, Cogni D, Riva C, Provini A. An in vitro biomarker approach for the evaluation of the ecotoxicity of non-steroidal anti-inflammatory drugs (NSAIDs). Toxicol In Vitro. 2009; 23(5): 935-942.

34. Fontes MK, Gusso-Choueri PK, Maranho LA, de Souza Abessa DM, Mazur WA, de Campos BG, Guimarães LL, de Toledo MS, Lebre D, Marques JR, Felicio AA, Cesar A, Almeida EA, Pereira CD. A tiered approach to assess effects of diclofenac on the brown mussel Perna perna: A contribution to characterize the hazard. Water Res. 2018; 132: 361-370.

35. Godoy AA, Kummrow F, Pamplin PAZ. Occurrence, ecotoxicological effects and risk assessment of antihypertensive pharmaceutical residues in the aquatic environment - A review. Chemosphere. 2015; 138: 281-291.

36. Matozzo V, Fabrello J, Masiero L, Ferraccioli F, Finos L, Pastore P, Di Gangi IM, Bogialli S. Ecotoxicological risk assessment for the herbicide glyphosate to non-target aquatic species: A case study with the mussel Mytilus galloprovincialis. Environ Pollut. 2018; 233: 623-632.

37. Dietrich S, Ploessl F, Bracher F, Laforsch C. Single and combined toxicity of pharmaceuticals at environmentally relevant concentrations in Daphnia magna - a multigenerational study. Chemosphere. 2010; 79(1): 60-66. 